\title{
What if Latinos Really Mattered in the Public Policy Debate?
}

\author{
Rachel F. Moran $\dagger$
}

The Articles that discuss "Policy, Politics, \& Praxis" try to answer a fundamental question: What if Latinos really mattered in the public policy debate? For this question to be of interest, there first must be an identifiable "Latino" constituency with common public policy concerns. In the section on "Race, Ethnicity, \& Nationhood," Professors Ian F. Haney López, Kevin Johnson, and Juan Perea address the complex questions of Latino identity. ${ }^{1}$ Here, Professors Robert S. Chang and Keith Aoki, Christopher David Ruiz Cameron, and Daria Roithmayr explore the role of Latinos in the public policy debate-an inquiry not wholly unrelated to the issue of Latino identity. After all, Max Weber observed that "it is primarily the political community, no matter how artificially organized, that inspires the belief in common ethnicity." 2 Consequently, examining Latinos' influence in the public policy arena can help to ascertain whether some cohesive constituency exists. If it does, including Latinos in policy discussions may be important purely as a matter of fair process. However, recognition of Latinos is particularly important if their participation significantly affects policy outcomes.

The papers that I introduce in this section focus on immigration and civil rights, two areas that offer potential insights into how Latinos might emerge as a distinctive constituency and alter public policy. Immigration seems a natural choice to evaluate the impact of Latinos as

Copyright $\odot 1997$ California Law Review, Inc.

† Professor of Law, Boalt Hall School of Law, University of California, Berkeley; A.B., 1978, Stanford University; J.D., 1981, Yale Law School.

1. See Ian F. Haney López, Race and Erasure: The Salience of Race to LatCrit Theory, 85 Calif. L Rev. 1143 (1997), 10 La Raza LJ. 57 (1997); Kevin R. Johnson, The Ring of Fire: Assimilation and the Mexican American Experience, 85 CALIF. L REv. 1259 (1997), 10 LA RAZA LJ. 173 (1997); Juan F. Perea, The Black/White Paradigm of Race: The "Normal Science" of American Racial Thought, 85 CALIF. L. REv. 1213 (1997), 10 LA RAZA L.J. 127 (1997).

2. MAX WEBER, ECONOMY AND SOCIETY 389 (Guenther Roth \& Claus Wittich eds. \& Ephraim Fischoff et al. trans., 1968). 
a group with a potentially unique stake in government decision-making. Even looking at only the Mexican-origin population, the influx of labor across the U.S.-Mexico border is the "largest sustained flow of migrant workers in the contemporary world." 3 Because the size and resources of the Latino population are integrally linked to immigration policy, Latinos logically should occupy a central place in this debate. Civil rights also seems like an area in which Latinos could make important contributions to government decisionmaking. By the year 2005, Latinos will surpass Blacks as the largest minority group in the United States; in some regions, this shift has already taken place. ${ }^{4}$ Like Blacks, Latinos lag behind Whites in education, income, and occupational attainment. As a result, programs of equal opportunity arguably are critical to Latinos' full integration into American society. 5

With two public policy areas that promise an important role for Latinos, I approached each paper in this section eager to learn how Latinos might emerge as an identifiable interest group and what changes they might prompt in immigration and civil rights law. However, even after reading three papers in a symposium devoted to Latinos, I was left with the odd impression that Latinos generally remain shadowy figures, little more than bit players in the policy process. Latinos are marginalized in these discnssions for two reasons. First, the Latino experience illustrates the other side of Weber's observation: latent contradictions in the political community can cloud rather than clarify identity. The heterogeneity of Latinos makes it difficult to generalize about their identities, experiences, and policy priorities. Because Latinos remain poorly understood, their probleins often are addressed by drawing analogies to other racial and ethnic groups. These ready analogies can obscure the special concerns of Latinos and prevent them from einerging as a complex and compelling people in their own right.

Second, even when Latinos figure in the policymaking process, the relevance of their participation reinains unclear. Should Latinos be considered because policymakers can then extend traditional paradigms of

3. Douglas S. Massey et al., An Evaluation of International Migration Theory: The North American Case, 20 Population \& Dev. Rev. 699, 705 (1994).

4. See Bureau of the Census, U.S. Dep't. of Com., P25-1130, Population Projections of the United States by Age, Sex, Race, and Hispanic Origin: 1995 to 2050, in CurRent Population ReP. 13 (1996); Paul R. Campbell, U.S. Dep't of Com., P25-1111, Population Projections for States, by Age, Sex, Race, and Hispanic Origin: 1993 to 2020, in Current Population ReF. 17 (1994) (showing that, as of 1993, Latinos already outnumber Blacks in Arizona, California, Colorado, Hawaii, ldaho, Maine, Montana, Nevada, New Hampshire, New Mexico, North Dakota, Oregon, Rhode Island, South Dakota, Texas, Utah, Vermont, Washington, and Wyoming).

5. See infra notes $37-42$ and accompanying text. 
immigration and civil rights to include them? Or should Latinos' concerns be evaluated so that policymakers can determine whether traditional models are adequate to meet their needs? If so, what alternative models would be necessary to address Latino issues? This uncertainty reflects and reinforces the ambiguities surrounding Latino identity. If Latinos' problems are analogous to those of other groups, traditional solutions should suffice. However, relying on traditional solutions overlooks the possibility that Latinos have distinctive needs. The very lack of alternative reform models makes it hard to imagine Latinos as a truly unique constituency. Yet, the failure to imagine them this way reduces the likelihood that alternative reforms will be considered.

\section{I \\ IMMigRation POLICY: ARE ASIAN-AMERICAN AND LATINO EXPERIENCES ANALOGOUS?}

To illuminate the uncertain role accorded to Latinos in the policy analysis here, let me begin by summarizing the paper on immigration. In "Centering the Immigrant in the Inter/National Imagination,"6 Professors Chang and Aoki describe the relationships among immigration, citizenship, and nationhood. They pose two key questions: "What negotiations must the immigrant make in traversing the border to gain entry into the United States? Once 'inside,' what other borders remain?"7 According to Chang and Aoki, "[a]lthough borders have become increasingly porous to flows of information and capital, borders are constricting when it comes to the movement of certain persons."8 They argue that "news of the nation-state's demise is premature" because "the nation-state is reasserting (and perhaps re-creating) itself through control over immigration and the immigrant."

Rather than romanticizing the immigrants' story, the authors insist on acknowledging the full extent to which explicitly racial overtones in immigration law and policy undercut a professed national commitment to colorblindness and equal citizenship. In their view, efforts to exclude immigrants turn on fears that newcomers from some racial groups will not assimilate to an American way of life. To support this view, Chang and Aoki cite Etienne Balibar's description of the European experience with racism and immigration: "It is a racism whose dominant theme is

6. 85 CaLIF. L. Rev. 1395 (1997), 10 La Raza L.J. 309 (1997).

7. 85 CALIF. L. Rev. at 1397, 10 LA RAZA L.J. at 311.

8. 85 CALIF. L. Rev. at 1398, 10 LA RAZA L.J. at 312.

9. 85 CaLif. L. Rev. at 1398, 10 LA RAZA L.J. at 312. 
not biological heredity but the insurmountability of cultural differences ...."10 In arguing that prejudice can be linked to culture as well as biology, the authors identify a particular brand of racism: nativistic racism. In coining the term, the authors explain that nativist movements in the United States have never been indiscriminately directed against foreigners-they have been directed against those immigrants who can be racialized. ${ }^{11}$

Chang and Aoki contend that the experience of immigrant populations reveals the dark side of American pluralism, which intensifies an awareness of differences, exacerbates racism, and makes race-neutral colorblindness an impossibility. ${ }^{12}$ Nativism and nationalism lead to internal borders that wall out racialized immigrant groups. Indeed, "[f]oreign-ness is inscribed upon [their] bodies in such a way that Asian-Americans and Latina/os carry a figurative border" within them which marks them as "targets of nativistic racism." 13 Chang and Aoki point to evidence that White Americans believe that they are under siege from racial minorities, resulting in calls for more vigorous border enforcement, elimination of affirmative action, less emphasis on multicultural curricula, and welfare reforms that deny aid to both legal and undocumented immigrants.

According to Chang and Aoki, rising numbers of Latino and Asian immigrants have created fears that America's national identity is in jeopardy. This national identity crisis in turn forces Americans to confront the role of race in defining the "good American." Americans must decide whether, as historian Arthur Schlesinger, Jr. claims, "[ $t]$ he American synthesis has an inevitable Anglo-Saxon coloration" that must be preserved to avoid "disintegration of the national community, apartheid, Balkanization, [and] tribalization."14

Chang and Aoki argue that even traditional forms of success can not shield a group from nativistic racism, as the case of the "model" minority, Asian Americans, demonstrates. The very success of Asian Americans, shown by high levels of education and employinent, makes them a model for less successful racial and ethnic groups, but a menace

10. 85 Calif. L. Rev. at 1041, 10 La RazA L.J. at 315 (citing Etienne Balibar, Is There a NeoRacism?, in Race, Nation, Class: Ambiguous Identities 17, 21 (Etienne Balibar \& Immanuel Wallerstein eds. \& Chris Turner trans., I99I)).

11. 85 Calif. L. Rev. at 1401-05, I0 LA RAZA L.J. at 315-19.

12. See 85 Calif. L, Rev. at 1401 n.19, 10 LA Raza L.J. at $315 \mathrm{n} .19$ (citing to WALTER BeNN Michaels, Our America, Nativism, Modernism, and Pluralism 65 (1995)).

I3. 85 CALIF. L Rev. at 1414, 10 LA RAZA L.J. at 328.

14. 85 CALif. L Rev. at 1413, 10 LA RAZA L.J. at 327 (citing ARThuR M. SChLesinger, JR., The Disuniting of America: Reflections on a Multicultural Society (1992)). 
to "real" Americans who fear displacement by "foreigners." As a result, an immigrant group prized for its industry and ambition can at the same time become a target of racial hate crimes. The authors argue that Asian Americans, like Latinos, are "perpetual internal foreigners, [who] allow 'real' Americans ... to reassure themselves that the national community begins and ends with themselves, ensuring, at least momentarily, a stable notion of the national community and the fiction of a homogeneous American identity."15

To illustrate the limitations of a model of assimilation, Chang and Aoki turn to a case study of Monterey Park, California. Confronted with rapid growth in both Asian-American and Latino populations, the formerly White, middle-class community experienced interracial and interethnic tensions. These strains were expressed through political demands for slow growth and official English. ${ }^{16}$ Throughout the city's struggle to redefine itself, its demographic transformation was seldom linked to global shifts in the economy that influence the flow of capital and labor across international borders. Instead, the controversy focused on domestic policy issues such as redistricting and municipal governance.

Despite common concerns about the backlash against immigrants in Monterey Park, Asian Americans and Latinos at best formed fragile and unstable coalitions. These alliances may have remained weak because of the racial, ethnic, linguistic, cultural, and class differences between the two groups. ${ }^{17}$ Latinos and Asian Americans in Monterey Park undoubtedly faced similar barriers of racism and hostility from the White community. Yet, these similarities were not enough to overcome the very different experiences of each group, or of the smaller groups within these monolithic labels, so that vital and enduring ties could be forged.

\section{A. The Uncertain Analogy Between Asian-American and Latino Experiences}

Chang and Aoki make important contributions to understanding the links between race, ethnicity, immigration, and citizenship. However, their paper seldom attempts to distinguish between Latinos and Asian Americans. Instead, the authors simply analogize Latinos to Asian Americans-at least for purposes of evaluating immigration and citizenship. For Chang and Aoki, the key point is that both Latinos and

15. 85 CALIF. L. Rev. at 1416, 10 LA RaZA L.J. at 330.

16. See 85 CaLIF. L. Rev. at 1427-31, 10 LA RAZA L.J. at 341-45.

17. See 85 CaLIF. L. ReV. at 431-38, 10 LA RAZA L.J. at 345-52. 
Asian-Americans are considered foreign and hence undesirable in the eyes of native-born Whites. Undoubtedly, these are important shared characteristics that affect immigration policy. What the authors largely ignore, however, are the significant differences between Latinos and Asian Americans. Still left to be explored, then, is whether their understanding of immigration law and citizenship theory would change if the Latino experience were at the center of the analysis.

The distinctions between Latinos and Asian Americans are significant enough to merit careful consideration before assuming that each group has similar policy needs. First, there is the matter of sheer numbers. Although Asian immigration has grown explosively in recent decades, Asian Americans remain a small part of the United States population. The sense of Asian Americans' foreignness undoubtedly stems in part from the fact that in 1994 nearly two-thirds of this population was foreign-born, and most had entered the United States since $1970 .{ }^{18}$ By contrast, the flow of Latinos into the United States has been substantial, steady, and longstanding. The growth of the Latino population is likely to continue. In fact, the Census Bureau predicts that by the year 2050, Latinos will outnumber Blacks, Asian Americans, and Native Americans combined. ${ }^{19}$ As of 1994 , only $38.5 \%$ of the Hispanic-origin population was foreign-born, and most had lived in the United States long enough to be eligible for naturalization. However, a mere $18.3 \%$ had become citizens. ${ }^{20}$

Although, historically, Asian immigrants were ineligible for citizenship, these racial restrictions on naturalization were lifted in $1952 .{ }^{21}$ The post-1965 Asian immigration to the United States has included significant numbers of highly skilled, urban professionals. ${ }^{22}$ By contrast, Latinos continue to enter largely as temporary laborers ineligible for citizenship. Between 1940 and 1992, only 1.2 million Mexicans entered the United States as legal immigrants, while 4.6 million came as temporary contract workers, and approximately four million entered

18. See Kristen A. Hansen \& Amara Bachu, U.S. Dep't of Com., P20-486, The Foreign-Born Population: 1994, in Current Population Rep.: Population Characteristics 2 (1995).

19. See Jennifer Cheeseman Day, U.S. Dep't of Com., P25-1104, Population Projections of the United States, by Age, Sex, Race, and Hispanic Origin: 1993 to 2050, in Current Population Rep. at xviii-xx (1993) (showing that Latinos will grow from $9 \%$ of the population in 1990 to $21.1 \%$ in 2050 , becoming the single largest minority group in the United States).

20. See id.

21. See Immigration and Nationality Act, Pub. L. No. 414, 66 Stat. 163 (1952), as amended, 8 U.S.C. sections 1101 et seq; see generally Ronald TAKAKI, Strangers From A DifFERENT SHORE 207, 413 (paperback ed. 1989).

22. See TAKAKI, supra note 21 , at $420-21$. 
without documents. By 1986, the population of undocumented immigrants who had resided in the United States for a substantial number of years was so large that about 2.3 million were legalized under the Immigration Reform and Control Act. In contrast to the general assumption that immigrants come to the United States with an expectation of citizenship, little more than twelve percent of Mexican-origin persons arrived with the formal option to make the United States their permanent home. ${ }^{23}$ Only after a period of uncertainty did the number who could remain in the United States as permanent resident aliens or citizens nearly triple through legalization.

Another significant difference between Latino and Asian immigrants is their proximity to countries of origin. Most Latino immigrants can travel back and forth with relative ease between the United States and their homelands, especially Mexico. As a result, transnational communities develop composed of international workers with ties to both the United States and the country of origin. ${ }^{24}$ These dual connections arguably impede rates of naturalization, even among Latino immigrants who are eligible for citizenship. In addition, preserving ties to the homeland is a particularly critical aspect of long-term survival for those who come as temporary workers or without documents because they cannot be sure the United States will remain their place of residence.

Consequently, Latinos do not necessarily fit traditional models of immigration which assume that newcomers will assimilate over time to an American way of life; instead, Latinos may persist as a bilingual and bicultural population to a greater degree than other immigrant groups. Transnational communities of bilingual, bicultural persons are a direct result of the imperatives of international migration and the restrictions of domestic immigration policy. The betwixt and between nature of many Latino migrants can create a sense of foreignness that is neither a figment of the nativist imagination, nor proof of Latino subversion of American values. Rather, the ambiguous status of transnational communities directly reflects unresolved policy dilemmas that pit the economic need for cheap labor against the political demand for linguistic and

23. See Massey et al., supra note 3 , at 705 .

24. See Rafael Alarcón, Labor Migration from Mexico and Free Trade: Lessons from a Transnational Community, in Chicano/Latino Pol'y Project Working PAPER 3, 18-21 (1994); Kevin R. Johnson, Los Olvidados: Images of the Immigrant, Political Power of Noncitizens, and Immigration Law and Enforcement, 1993 BYU L. REV. 1139, 1223 (citing IMMIGR. \& Naturalization Serv., U.S. Dep't. of Justice, 1991 Stat. Y.B. OF the IMmigr. \& Naturalization Serv, 120). 
cultural coherence. In short, America wants the work without the worker. ${ }^{25}$

Moreover, immigration policy cannot account entirely for the Latino experience in the United States. In contrast to Asian Americans, not all Latinos have entered the United States as voluntary immigrants. Persons of Puerto Rican and Mexican origin, the two Latino sub-groups with the poorest outcomes in terms of education and employment, have a history of territorial annexation. Indeed, Puerto Ricans today are not immigrants at all, for they are United States citizens by birth. Despite their status as citizens, they continue to suffer from the lowest rates of educational attainment, the most depressed rates of income and employment, and the highest rates of out-of-wedlock pregnancies and single-parent households of the major Latino sub-groups. ${ }^{26}$

Although legacies of conquest often are dismissed as nothing more than ancient history, they continue to influence public policy in important ways. In particular, this history of conquest uniquely complicates the links between racial categorization and subordination. For example, in the Southwest, following wars that resulted in annexation of large areas of Mexican territory, treaties provided that formerly Mexican citizens would receive equal treatment from the United States government. As a result, Latinos typically were not included in state statutes that required segregation of Blacks and Asian Americans from Whites. Instead,

25. For a description of persistent bilingual and bicultural identities among Latinos, especially those in border communities, see Rachel F. Moran, Foreword-Demography and Distrust: The Latino Challenge to Civil Rights and Immigration Policy in the 1990s and Beyond, 8 LA RAzA L.J. 1, 19-21 (1995).

26. See Bureau of the Census, U.S. Dep't of Com., 1990 CP-3-3, 1990 Census of Population: Persons of Hispanic Origin in the United States 43-47, 81-85, 119-23, 157-61 (1993) (explaining that of Mexicans, Puerto Ricans, Cubans, and "other Hispanics," Puerto Ricans have the lowest percentage of children under the age of 18 living with two parents; Pucrto Ricans lave lower rates of educational attainment than Cubans and other Hispanics; among persons 16 years and over, Puerto Ricans have higher rates of unemployment and lower levels of mean and niedian family income than Mexicans, Cubans, and other Hispanics; but Puerto Rican per capita income and educational attainment is somewhat higher than that of Mexicans); see also Nancy A. Denton \& Douglas S. Massey, Trends in the Residential Segregation of Blacks, Hispanics, and Asian-Americans By Socioeconomic Status and Generation, 69 Soc. Sct. Q. 797, 807 (1988) (stating that Cubans and Mexicans enjoy access to integrated neighborhoods with rising status, but Puerto Ricans do not); Thomas J. Phelan \& Mark Schneider, Race, Ethnicity, and Class in American Suburbs, 31 URB. AFF. REv. 659, 668 (1996) (arguing that Puerto Ricans are least economically successful of all major Latino groups); Cordelia W. Reimers, Sources of the Family Income Differentials Among Hispanics, Blacks, and White Non-Hispanics, 89 AM. J. Soc. 889, 891 (1984) (establishing that Puerto Ricans have lowest mean family income of major Latino groups); Marta Tienda, Latinos and the American Pie: Can Latinos Achieve Economic Parity?, 17 Hispanic J. Behav. Scr. 403, 412 (1995) (declaring that Puerto Ricans, compared to Mexicans, experienced a higher poverty rate, lower male workforce participation, and more single-parent families). 
informal barriers to opportunity were used to exclude Latinos who were "White but not quite." 27 These barriers included discrimination in housing that kept persons of Mexican origin in neighborhoods with low property values and inferior municipal services, including inadequate schooling. Before the advent of civil rights consciousness in the postWorld War II era, employers could discriminate against Mexican-origin persons with impunity, keeping them in low-wage jobs with little hope of advancement. ${ }^{28}$ The historical treatment of Mexican-origin individuals as formally White and informally non-White has created ongoing ambiguities about the role of race in shaping their opportunities, whether they are immigrants or not.

\section{B. The Implications of Distinct Asian-American and Latino Experiences for Immigration Policy}

By equating the Asian and Latino immigration experiences, Chang and Aoki fail to acknowledge fully the distinct conundrums that each group poses for public policymakers. A traditional model of immigration assumes that immigrants arrive by invitation only, remain in the United States and renounce all former allegiances, and by dint of hard work sacrifice themselves so that their children and grandchildren can achieve the American dream. ${ }^{29}$ This nostalgic account of the immigrant experience is seriously flawed, even for White ethnic arrivals; still, it continues to dominate popular imagery and policy discussions of the "good immigrant." 30

27. See, e.g., Tomás Almaguer, Racial fault lines: The Historical Origins of White SuPREMACY IN CALIFORNIA 45-104 (1994) (describing protections under the Treaty of Guadalupe Hidalgo of 1849 and the discrimination in California of the 1800 s which nevertheless divested elites of Mexican origin of their property and kept working-class people of Mexican origin trapped at the low end of the occupational scale).

28. See, e.g., David Montejano, Anglos and Mexicans in the Making of Texas, 18361986 at 159-96 (1987) (describing practices of discrimination and segregation in education, housing, and employment that limited the social mobility of persons of Mexican origin in Texas in the period from 1920 to 1940 ).

29. For a fuller treatment of the traditional model of immigration and its limitations, see Rachel F. Moran, Neither Black Nor White, 2 HaRv. Latino L. Rev. (forthcoming 1997); Rachel F. Moran, Unrepresented, 55 REPRESENTATIONS 139, 146-48 (1996); Moran, supra note 25, at 16-22.

30. See David A. Hollinger, Postethinic America: Beyond Multiculturalism 152 (1995) (noting that one-third of immigrants returned to their countries of origin during the great migration of 1880 to 1924); see generally James F. Smith, United States Immigration Policy-A History of Prejudice and Economic Scapegoatism?: A Nation that Welcomes Immigrants? An Historical Examination of United States Immigration Policy, 1 U.C. DAVIS J. INT'L L. \& PoL'Y 227 (1995) (contending that a traditional model of immigration is not applied to Latinos and Asians, who have historically been excluded from entry into the United States); Ruben J. Garcia, Comment, Critical Race Theory and Proposition 187: The Racial Politics of Immigration Law, 17 Chicano- 
As Chang and Aoki note, Asian Americans have been labeled the model minority because first-generation immigrants, in spite of their racial status, have been able to lay the foundation for the notable educational and economic success of their children and grandchildren. Asian Americans thus appear to be the quintessential immigrant success story, often touted as proof that race need not be an obstacle to achieving the American dream. ${ }^{31}$

For government officials, the challenge has been to determine whether Asian Americans, who are widely regarded as a distinct race, in fact are a racial minority. Numerically, they are a small population, but if the term "minority" depends on disadvantaged status, Asian Americans do not seem to have the same claim to public resources aimed at achieving racial equality as do other groups, particularly Blacks. Asian-American advocates respond that not all Asian subgroups have enjoyed equivalent success. For example, Indochinese refugees do not fare as well as more established groups like the Chinese, Japanese, and Koreans. ${ }^{32}$ Moreover, those who insist on minority status for Asian Americans point out that even the most successful Asian Americans pay a racial tax not borne by Whites. That is, Asian Americans obtain a lower rate of return on their educational investment than Whites; their remarkable success is due to their willingness to compensate for this discrimination by investing more in education than Whites do.33

LATINO L. REv. 118, 122-29 (1995) (arguing that immigration law reflects racial biases that exclude certain groups, such as Latinos, from the benefits of citizenship while using those groups' labor to build the nation).

31. See Pat K. Chew, Asian Americans: The "Reticent" Minority and Their Paradoxes, $36 \mathrm{WM}$. \& MARY L. REV. 1, 6-7, 24-31 (1994) (describing the depiction of Asian Americans as a model minority and its distortion of Asian-American experiences); Jennifer L. Hochschild, The Word American Ends in "Can": The Ambiguous Promise of the American Dream, 34 WM. \& MARY L. Rev. 139, 165-66 (1992) (describing media fascination with Southeast Asians as an immigrant succcss story despite efforts to point out that not all immigrants have been able to escape the strictures of poverty, crime, and discrimination); Frank H. Wu, Changing America: Three Arguments About Asian Americans and the Law, 45 AM. U. L. REv. 811, 814-15, 818 (1996) (noting empirical evidence that supports the characterization of Asian Americans as a model minority, but arguing that the model minority label is a persistent myth with invidious consequences).

32. See Chew, supra note 31, at 25-30. But cf. Harry H.L. Kitano, Asian-Americans: The Chinese, Japanese, Koreans, Pilipinos, and Southeast Asians, 454 Annals AM. ACAD. Pol. \& Soc. ScI. 125, 126-27, 130, 137-38 (1981) (describing the internal diversity of the Asian-American community, but arguing that all groups appear to be following the pattern of voluntary immigration despite prejudices, discrimination, and segregation).

33. See Charles Hirschman \& Morrison G. Wong, Socioeconomic Gains of Asian Americans, Blacks, and Hispanics: 1960-1976, 90 AM. J. Soc. 584, 595, 599-600, 602-03 (1984); see also David Lauter, Minorities Adding Up to a Majority, TIMES UNION, Apr. 2, 1995, at E1 (noting high income and education levels among Asian Americans). 
Policy analysts have not been wholly persuaded by these arguments. Their research often links sub-group differences to recency of arrival, suggesting that the longer the time of residence, the more successful the group. Under this view, sub-group differences will fade as newly arrived populations achieve intergenerational assimilation. ${ }^{34}$ Based on evidence of housing integration and intermarriage of Whites and Asian Americans, some policymakers believe that even the residual racial tax on highly educated Asian Americans will disappear with further opportunity for assimilation and the elimination of vestiges of negative stereotyping. ${ }^{35}$

Latinos present a distinctive problem: They appear to be a minority without being clearly identified as a racial minority. Unlike Asian Americans, Latinos are not formally classified as a race. The Census permits Latinos to be of any race, and most of those who select a racial designation choose "White."36 Yet, based on their depressed levels of education and income, Latinos seem to qualify as a minority-albeit an ethnic one. Critics of the decision to include Latinos along with Blacks in affirmative action programs argue that Latinos' low socioeconomic status is an artifact of heavy immigration, rather than permanent disadvantage based on race or ethnicity. These critics contend that large numbers of recent immigrants with limited schooling and skills create a misleading impression of disadvantage based on ethnic discrimination. According to this view, Latinos, like other White ethnic groups, will assimilate over time, and disparities in education and income will disappear naturally without substantial government intervention. ${ }^{37}$

34. See Denton \& Massey, supra note 26, at 810-13; William H. Frey \& Reynolds Farley, Latino, Asian, and Black Segregation in U.S. Metropolitan Areas: Are Multiethnic Metros Different?, 33 Demography 35, 38-39 (1996).

35. See Douglas S. Massey \& Nancy A. Denton, Trends in the Residential Segregation of Blacks, Hispanics, and Asian-Americans: 1970-1980, 52 AM. SoC. REv. 802, 823 (1987). But cf. Chew, supra note 31, at 8, 32-70 (noting and questioning claims that Asian Americans can achieve full integration into American society and no longer experience discrimination).

36. See Race and Ethnic Standards for Federal Statistics and Administrative Reporting, 43 Fed. Reg. 19260 (1977); Bureau of the Census, U.S. Dep't of Com., 1990 CP-2-1, 1990 Census of Population: Social and Economic Characteristics of the United States 4 (1993) (reporting that of those who identify themselves as being of Hispanic origin on the 1990 Census, 11,402,291 say they are "White," 9,470,850 say they are "Other," 645,928 say they are "Black," 232,684 say they are "Asian or Pacific Islander," and 148,336 say they are "American Indian"); see generally Harvey $M$. Choldin, Statistics and Politics: The "Hispanic Issue" in the 1980 Census, 23 DemoGRAPHY 403, 40813 (1986) (noting that most Latinos self-identify as White).

37. See Marta Tienda \& Ding-Tzann Lii, Minority Concentration and Earnings Inequality: Blacks, Hispanics and Asian-Americans Compared, 93 AM. J. Soc. 141, 164 (1987); see also Peter H. Schuck, Alien Rumination, 105 YALE LJ. 1963, 1999-2004 (1996). 
Other commentators disagree with this rosy assessment. They contend that Latinos suffer from "blocked assimilation" because ethnic discrimination limits the opportunities of second-generation and thirdgeneration Latinos by confining them to low-income, segregated neighborhoods with inadequate schooling and limited job opportunities. ${ }^{38}$ In some ways, these researchers argue, second-generation and thirdgeneration Latino youths are worse off than their first-generation forebears. While newcomers express optimism about and satisfaction with their opportunities in the United States, their children and grandchildren report a sense of skepticism and failure. As a result, second-generation and third-generation Latinos are more apt than first-generation immigrants to succumb to the perils of life in the American underclass. ${ }^{39}$ In short, the hard work of first-generation Latinos is not necessarily rewarded by the success of their children and grandchildren.

Asian-American and Latino experiences play very different roles in policy accounts of the interaction of race, ethnicity, and immigration. Asian-American success is used to undercut claims that race is an insurmountable obstacle to success and to argue that race-based remedies like affirmative action are not needed to ensure meaningful access to education and employment. For policymakers, Asian Americans show that through hard work and ability, individuals can make it without government assistance, even if they are non-White.

38. This argument focuses on access to education and employment. The limited demographic research available suggests that Latinos earn a wage similar to that of Whites once they have learned English and attained comparable schooling. Latinos with limited language proficiency earn less than Whites with similarly limited proficiency. See, e.g., Gillis Grenier, The Effects of Language Characteristics on the Wages of Hispanic-American Males, 19 J. HuM. RES. 35 (1984); Walter McManus et al., Eamings of Hispanic Men: The Role of English Language Proficiency, 1 J. LAB. ECON. 101 (1983); Ross M. Stolzenberg \& Marta Tienda, English Proficiency, Education, and the Conditional Economic Assimilation of Hispanic and Asian Origin Men, 26 Soc. ScI. RES. 25, 43 (1997). Proponents of a theory of blocked assimilation focus on the barriers to education and training that hamper second-generation and third-generation Latinos trapped in ethnically identifiable, lowincome neighborhoods with dual labor markets. See, e.g. Harry P. Pachon \& Joan Moore, Mexican Americans, 454 AnNals AM. ACAD. Pol. \& Soc. Sc1. 111, 118-20 (1981).

39. See generally IN THE BARRIOS: LATINOS AND THE UNDERClass Debate (Joan Moore \& Raquel Pinderhughes eds., 1993); Jorge Chapa, The Question of Mexican-American Assimilation: Socioeconomic Parity or Underclass Formation?, 35 PUB. AFF. CoMment. 1, 6 (1988); Jorge Chapa \& Richard R. Valencia, Latino Population Growth, Demographic Characteristics, and Educational Stagnation: An Examination of Recent Trends, 15 HiSPANIC J. BEHAv. ScI. 165, 183-84 (1993); Herbert J. Gans, Second-Generation Decline: Scenarios for the Economic and Ethnic Futures of the Post-1965 American Immigrants, 15 EThNIC AND Racial STud. 173, I81-83, 188-89 (1992); David E. Hayes-Bautista \& Gregory Rodriguez, California: Next Year, We Will All Be Minorities, LA. TIMES, Aug. 13, 1995, at M1. 
The Latino experience confounds the links between race and immigration by showing that even if a group's members can formally be considered White, their full participation in American life can be thwarted. As the treatment of Latinos illustrates, official policies about race afford little protection when widespread, informal discrimination persists. Even though a substantial number of Latinos self-identify as White, they continue to be the object of negative stereotyping..$^{40}$ Latinos have lower rates of education and income than Whites, and except for the most accomplished, Latinos do not earn wages comparable to Whites. ${ }^{41}$ Despite their formal classification as an ethnic rather than racial group, Latinos continue to live in segregated neighborhoods. ${ }^{42}$

Moreover, the Latino experience challenges the assumption that assimilation is a natural phenomenon that automatically leads to intergenerational upward mobility. Blocked assimilation suggests that Latinos acculturate to the role of a disadvantaged minority with limited opportunities. Because of continuing prejudice, Latino immigrants cannot count on the full integration of their children and grandchildren into American society as a reward for their hard work in the marginal jobs that newcomers occupy.

Although the portrait of Latino immigrants is not clearly delineated in their paper, Chang and Aoki rely on a composite image of Asian and Latino newcomers to suggest that an alternative to the traditional model of immigration is needed. The contours of this alternative are not entirely clear. The authors seem to argue that the United States should

40. See Thomas C. Wilson, Cohort and Prejudice: Whites' Attitudes Toward Blacks, Hispanics, Jews, and Asians, 60 PUB. OpIN1ON Q. 253, 260 (1996) (reporting that stereotypes are most unfavorable for Blacks and Latinos).

41. See Bureau of the Census, U.S. Dep't of Com., supra note 36, at 154-55 (reporting that, according to the 1990 Census, median income of families not of Hispanic origin was $\$ 36,028$, while that of families of Hispanic origin was $\$ 25,064$; mean income of non-Hispanic origin families was $\$ 44,802$ while that of Hispanic origin families was $\$ 31,195$; per capita income of persons not of Hispanic origin was $\$ 15,002$, while that of persons of Hispanic origin was $\$ 8400$ ); Reynolds Farley, Blacks, Hispanics, and White Ethnic Groups: Are Blacks Uniquely Disadvantaged?, 80 AM. EcoN. REv. 237, 240 (1990) (arguing that Latinos of Mexican origin, like Blacks and Native Americans, are at a double disadvantage because they have limited education and also earn below-average rates of return on the skills they possess); Hirschman \& Wong, supra note 33, at 593, 596 (finding that Black and Latino males are the most disadvantaged in the labor market; the gap between White and Black income is larger than the gap between Latino and White income; but while the gap narrowed steadily for Blacks during the 1960 s to 1976 there was no progress for Latinos during the same time period); Cordelia W. Reimers, supra note 26, at 889 (noting that as of the 1981 Census, Latino family income was $72 \%$ of White family income).

42. See Phelan \& Schneider, supra note 26 , at $661,664,670-72,673-74$ (arguing that Latinos face increasing segregation and that compared to Whites, Latinos who live in suburban areas are in less affluent suburbs, face lower property value growth rates, and have a higher tax rate). 
refrain from a new brand of cultural racism, yet this term conflates culture and race in a way that is particularly undesirable in evaluating the situation of Latinos. Latinos have not been as clearly racialized as Asian newcomers-at least insofar as racialization is measured by formal racial classification schemes and statutes that have explicitly segregated groups based on race. ${ }^{43}$ By virtue of their proximity to home countries, however, Latinos develop transnational ties that perpetuate distinctive linguistic and cultural practices, a pattern that may not occur to the same extent among Asian immigrants. Consequently, cultural distinctiveness may be divorced from formal racialization in unique ways for Latinos.

One way of addressing barriers to full incorporation under the traditional immigration model is to insist on its race-neutral application; that is, all immigrants must enjoy the same opportunity to assimilate gradually to an American way of life, regardless of their country of origin. All groups ought to have the same chance to realize the promise of intergenerational mobility, whether European, Asian, African, or Latin American. Of course, Latinos, like Asians, would benefit from efforts to make the traditional model more inclusive than it has been. A large proportion of Latinos has entered the United States without promises of permanency or long-term integration into American society. As a result, they are not even included in a model that offers a promise of equality through intergenerational mobility. If prejudice accounts in part for the tendency to treat Latinos as temporary workers rather than potential citizens, the United States should increase the number of Latino workers who enjoy the opportunity to naturalize and settle permanently under a race-neutral version of the traditional immigration paradigm.

Making the traditional model race-neutral works best for immigrants who, apart from initial negative stereotypes of first-generation immigrants based on national origin, otherwise fit the model's assumptions. That is, they come by invitation, have the opportunity to naturalize, and have attenuated contact with their countries of origin. As already demonstrated, the Latino experience, perhaps more than the Asian-American experience, deviates from this framework. As a result, it is difficult for Latinos to thrive under a traditional model-even one

43. See Ronald Takaki, A Different Mirror: A History of Multicultural america 177-84 (1993) (noting that Mexican-origin population in California and Texas enjoyed formal protections against racialization under treaties, but these protections were subverted in practicc); TAKAKI, supra note 21, at 201-03, 245-47, 272 (detailing formal segregation of persons of Chinesc, Japanese, and Korean descent based on race); Peggy Pascoe, Race, Gender, and Intercultural Relations: The Case of Interracial Marriage, 12 Frontrers 5, 7 (1991) (noting that antimiscegenation laws were applied most stringently to Asians, but did not cover Latinos). 
that aspires to formal racial neutrality. Under a race-neutral model, proximity to the homeland and transnational ties might still make Latinos seem somehow disloyal and foreign. As a result, they could be penalized for failing to acculturate, a sanction that would focus on mutable traits like language and culture rather than the immutable trait of race. To fully include Latinos, the United States might have to adopt an alternative model of immigration, one that recognizes the impact of a globalized economy in which capital and labor regularly flow across international borders. Rather than require immigrants to shed their earlier ties, a transnational model could recognize that dual identities are a natural artifact of the global marketplace, and that bilingualism and biculturalism are assets rather than threats to national integrity. ${ }^{44}$

Chang and Aoki's paper contributes to the discussions about the impact of transnationalism that already are taking place in international law and immigration circles. Scholars are exploring not only what it means to be a good immigrant, but also what it means to be a good American. Some have argued that America is a country predicated on liberal individualism; freedom to make personal choices about one's identity are maximized, and one's Americanness resides in a commitment to democratic processes of self-governance. Under this sort of "thin" liberalism, which requires loyalty to process more than to substantive normative values, transnational affiliations are simply part of the package of liberties that Americans enjoy. On the other hand, prominent constitutional scholars have argued that America is in jeopardy because it has lost a sense of civic republicanism or communitarianism. Bent on the atomistic pursuit of self-actualization, Americans have ceased to engage in meaningful dialogue about core civic values and have lost a sense of community based on a shared culture and heritage. ${ }^{45}$ For republicans and communitarians, transnationalism is simply a further assault on American identity and cohesion, one that highlights how a notion of a uniquely American identity has seriously deteriorated. 46

44. See Moran, Neither Black Nor White, supra note 29; Moran, supra note 25, at 22.

45. See, e.g., Bruce A. Ackerman, The Storrs Lectures: Discovering the Constitution, 93 YALE L.J. 1013, 1033-34 (1984); Frank Michelman, Law's Republic, 97 YALE L.J. 1493, 1503-15 (1988); Cass R. Sunstein, Beyond the Republican Revival, 97 YALE L.J. 1539, 1566 (1988).

46. See Stephen H. Legomsky, Why Citizenship?, 35 VA. J. INT'L L. 279, 295-98 (1994); David A. Martin, The Civic Republican Ideal for Citizenship, and for Our Common Life, 35 VA. J. INT'L L. 301, 308-18 (1994); Gerald L. Neuman, Justifying U.S. Naturalization Policies, 35 VA. J. INT'L L. 237, 270-71, 276-77 (1994). 
Chang and Aoki's example of racial and ethnic division in Monterey Park undoubtedly confirms some of the ivorst fears that republicans and communitarians harbor about the consequences of transnationalism. The strife in this municipality seems to suggest that the democratic process alone offers insufficient protection against a vanishing sense of community and a declining commitment to the common good. Rather than simply attribute the conflict to White nativism, republicans and communitarians see this disharmony as the inevitable byproduct of patchwork populations without a shared heritage or experience. To support this view, republican and communitarian scholars could point to the way in which conflict between established and newly arrived residents cut across racial and ethnic lines in Monterey Park. When Chinese immigrants arrived in substantial numbers, not only Whites but also Latinos fled the area. ${ }^{47}$ Moreover, although nativist supporters of official English were mainly White, the movement also attracted some Latinos and Japanese Americans alarmed by the influx of Chinese immigrants. ${ }^{48}$ As one Japanese-American resident complained to his father, "God damn it, Dad, where the hell did all these Chinese come from? Shit, this isn't even our town anymore."49

If Chang and Aoki truly have in mind a transnational model of immigration and citizenship, it would be useful to provide a positive example of how it might work to shape a successful American experiment with diversity in local government. Chang and Aoki focus on the success of redistricting efforts in managing racial and ethnic conflict and competition, but Monterey Park offers additional evidence of a rapprochement among old and new constituencies that transcends racial and ethnic divisions. For instance, nativist city leaders were defeated in part by declining support among White residents who felt that local politics had become too balkanized, confrontational, and destructive. Coalitions of women from diverse racial and ethnic backgrounds played a particularly important role in healing rifts within the community. 50 With the decline of nativist politics, leaders were able to disaggregate legitimate concerns about the problems of gridlock and overdevelopment from the invocation of "slow growth" or "no growth" as code

47. See John Horton, The Politics of Diversity in Monterey Park, California, in Structuring Diversity: Ethnographic Perspectives on the New Immigration 215, $222-23$ (Louise Lamphere ed., 1992).

48. See id. at 228.

49. Id. at 226 .

50. See id. at 233-37. 
words for anti-Chinese sentiment. 51 By examining the long-term political outcomes in Monterey Park, the authors might provide an even better sense of the resiliency of the democratic process, the accommodation of diverse groups, and the forging of a new sense of American community.

II

\section{Civil Rights: ARe Black and Latino Experiences ANalogous?}

In contrast to the discussion of immigration, the papers on civil rights in this section clearly reflect the dominant influence of the Black experience on public policy. In dealing with employment discrimination and affirmative action, each author must assess whether a traditional civil rights framework predicated on the history of slavery and segregation suffered by African Americans fits the situation of Latinos. In "How the Garcia Cousins Lost Their Accents: Understanding the Language of Title VII Decisions Approving English-Only Rules as the Product of Racial Dualism, Latino Invisibility, and Legal Indeterminacy," 52 Professor Cameron shifts from Chang and Aoki's focus on conditions for participating in American society generallyby obtaining citizenship- to the conditions for participating in the American workforce. Cameron's article looks at employees who have already assimilated to some degree by learning English. Rather than being monolingual, however, they retain facility in another language, typically Spanish. The question that arises is the extent to which employers can regulate the use of a language other than English in the workplace without discriminating on the basis of national origin.

Cameron's article demonstrates that employers can engage in surprisingly intrusive language regulation on the job without being guilty of discrimination. Workers can be terminated for using a language other than English in violation of an English-only rule, even if the conversation involves only a few words and does not otherwise impede performance of assigned tasks. To add insult to injury, employees can be discharged for using a language other than English, even if they were hired because they had bilingual skills. The employer can set the boundaries for using a language other than English, and employees cannot expand these limits at their discretion. ${ }^{53}$

51. See id. at 224-25, 243-44.

52. 85 CALIF L. Rev. 1347 (1997), 10 LA RAZA L.J. 261 (1997) [hereinafter Cameron].

53. See 85 Calif. L. Rev. at 1349,10 LA RazA L.J. at 245. 
To understand why bilingual workers have not enjoyed more protection under employment discrimination laws, Cameron offers three explanations. First, he argues that under a Black/White model of race relations, federal courts have been unable to appreciate forms of discrimination that uniquely disadvantage Latinos. The Black/White model is rooted in the belief that race is an immutable characteristic, an assumption that undergirds the corrective justice framework in employment discrimination law. At its core, corrective justice requires that workers not be penalized for traits that they cannot change and that are not job-related. Because language is a mutable characteristic, individuals can acquire the ability to speak English. Once they master English, they can choose to speak it if the employer deems it beneficial. Therefore, the courts' view is that for the bilingual worker, the requirement of speaking in English is not a form of discrimination, but rather a mere inconvenience. 54

Second, Cameron contends that the Black/White paradigm has rendered Latinos invisible in public policy debates. Consequently, case law on English-only rules does not carefully analyze the use of Spanish on the job to see if it is disruptive; in fact, courts do not even describe the proscribed utterances or their workplace context in any detail. Rather, the very use of Spanish is seen as a demand for visibility by Latinos that "offends and frightens many English-only speakers, who sense in the language a loss of control over what they regard as 'their' country."55 The insistence on using Spanish violates the Latino's role as a deferential employee. Indeed, the purported ease with which the bilingual worker can comply with the English-only rule makes the decision to speak Spanish seem like an act of insubordination, one for which the worker should be demoted or fired.56

Third, Cameron asserts that legal indeterminacy has permitted courts to manipulate outcomes in cases affecting Latino litigants. He claims that national origin discrimination has never been as clearly defined as racial discrimination under federal employment discrimination

54. See Garcia v. Spun Steak Co., 998 F.2d 1480, 1487-88 (9th Cir. 1993); Long v. First Union Corp. of Virginia, 894 F. Supp. 933, 941 (E.D. Va. 1995), aff'd, 86 F.3d 1151 (4th Cir. 1996). For an interesting discussion of other areas in which the law has penalized individuals because they do not fit neatly into existing categories for defining discrimination, see generally RUTH COLKER, HYBRID: Bisexuals, Multiracials and Other Misfits Under American law (1996).

55. Cameron, 85 Calif. L. REv. at 1380, 10 LA RazA L.J. at 294 (quoting Juan F. Perea, Los Olvidados: On the Making of Invisible People, 70 N.Y.U. L. REv. 965, 965 (1995)).

56. See 85 Calif. L. REv. at 1368-69, 10 LA RazA L.J. at 282-83. For another discussion of how a Black/White paradigm has limited attention to the unique needs of Latinos, see Perea, 85 Calif. L. REv. at 1213, 10 LA RAZA L.J. at 127. 
law. As a result, judges have been able to reject bilingual workers' allegations of discrimination by recasting their demands to speak Spanish on the job as an effort to gain recognition of a language preference, a demand to privilege their cultural expression. The courts have rejected this purported demand for special treatment as beyond the scope of protection for national origin. Judges have spent far less time explaining what protection against national origin discrimination means if it does not encompass rights to linguistic and cultural expression. For instance, the Equal Employment Opportunity Commission has promulgated guidelines that characterize broad rules requiring employees to speak only in English as national origin discrimination. Nevertheless, federal courts have rejected the guidelines as exceeding the Commission's authority without explaining how acceptable alternative guidelines might be drafted. ${ }^{57}$

Like Chang and Aoki, Cameron argues that rules for assimilation, depicted as race-neutral and non-discriminatory, in fact disadvantage newcomer groups like Latinos. He calls for courts and agencies to recoguize English-only rules as a form of discrimination that needlessly marginalizes a growing segment of America's workforce. Cameron contends that simply because an employee is bilingual, his decision to speak another language should not be interpreted as insubordination. In his view, language and culture are products of national origin that cannot simply be turned on and off at will to satisfy an employer. Moreover, he argues that an einployer's preference for English in the workplace cannot automatically be privileged over an employee's preference for a language other than English. Because of the close links between a worker's language, culture, and identity, employers should be required to show that an English-only rule is justified by business necessity. ${ }^{58}$ In short, Cameron would alter the definition of the "good American worker" to mean one who is tolerant of differences in a pluralistic employment setting, rather than one who is required to assimilate more fully by minimizing linguistic and cultural differences.

In "Deconstructing the Distinction Between Merit and Bias,"59 Professor Roithmayr exainines a group arguably even more assimilated than bilingual workers: applicants for higher education, particularly law school education. Using deconstruction to demonstrate the

57. See Cameron, 85 CAlif. L. Rev. at 1388-92, 10 LA Raza L.J. at 302-06; see, e.g., Garcia, 998 F.2d at 1489-90 (rejecting EEOC guidelines); Long, 894 F. Supp. at 940 (same).

58. See Cameron, 85 Calif. L. REv. at 1389-91, 10 LA RAzA L.J. at 303-05.

59. 85 CALIF. L. REv. 1449 (1997), 10 LA RAZA L.J. 363 (1997) [hereinafter Roithmayr]. 
interdependency of notions of merit and bias, she challenges Daniel Farber and Suzanna Sherry's claim that traditional definitions of merit are the most rational means of ranking applicants because they provide an unbiased, objective measure of individual ability.

Like Chang and Aoki, Roithmayr argues that standards that appear to be race-neutral are in fact deeply infected by racism. Relying on Professor Gerold Auerbach's historical account of legal education, Roithmayr contends that in the 1920s law school admissions standards were indirectly created by, if not directly motivated by, virulent antiimmigrant sentiment and anti-Semitism in the legal profession. ${ }^{60}$ Concerned that newcomers might enter elite preserves of power and authority, law schools worked with professional associations to develop strategies of exclusion. ${ }^{61}$ She notes that reformers often masked their antipathy by emphasizing a concern with preserving the moral character of the bar. For example, a former president of the American Bar Association, Elihu Root, worried that some attorneys were entering practice "who ha[ve] not any conception of the moral qualities that underlie our free American institutions." 62 Another prominent attorney justified raising standards for admission to the bar on the ground that "foreigners" in the cities threatened the integrity of the legal profession because they were "an uneducated mass of men who have no conception of our constitutional government." 63

Having looked at the unsavory history of excluding foreigners from the profession, Roithmayr argues that affirmative action can be understood as the most rational and, hence, meritorious selection process available because diversity in law schools is an appropriate response to past exclusionary policies. Far from embodying illicit racial bias, affirmative action overcomes the bias inherent in processes rooted in disgraceful acts of past discrimination. For Roithmayr; Grade Point Averages (GPAs) and Law School Admission Test (LSAT) scores are as much a function of racial and cultural differences as they are a reflection of ability and hard work. In an academic competition tainted by a history of discrimination and exclusion, numbers that appear to be scientific are, at best, imperfect measures of the "good student." Moreover, insofar as law schools are centrally implicated in the

60. See 85 Calif. L. Rev. at 1482, 10 La RazA L.J. at 396.

61. See 85 Calif. L. Rev. at 1482-86, 10 LA RazA L.J. at 396-400.

62. 85 CALIF. L. Rev. at 1482-83, 10 LA RAza L.J. at 396-98.

63. 85 CALtF. L. Rev. at 1482, 10 LA RAzA L.J. at 396 (quoting Professor Auerbach's description of remarks by a member of the Root Committee, which was appointed to study legal education in the 1920s). 
allocation of wealth and power, members of racially subordinated groups should enjoy a say in building the profession and redistributing social opportunity. By creating a core minority intelligentsia, affirmative action is a plausible means of overcoming past bias and promoting diversity. ${ }^{64}$ Based on this view, Roithmayr argues that law schools can and should defend affirmative action programs on the ground that numerical indices for admission, such as GPAs and LSAT scores, do not correlate sufficiently with law school performance to overcome their tainted history. 65 With an eye to current efforts to eliminate affirmative action at law schools in California and Texas, she suggests that her analysis could transform current approaches to defining unlawful discrimination by reallocating the burden of justifying criteria with a disproportionate racial impact from Black and Latino applicants to law school administrators.

In the end, though, Roithmayr concedes that there is no foolproof way to choose on rational grounds between Farber and Sherry's defense of traditional meritocratic criteria and her defense of affirmative action. Farber and Sherry argue that the traditional standards are objective and non-discriminatory by pointing to the success of previously excluded groups, such as Asian Americans and Jews, in meeting these criteria. Roithmayr contends that the traditional standards perpetuate an unfair status quo by citing the limited presence of Blacks and Latinos, even with affirmative action programs. Because there is no way to prove conclusively that one account is right and the other wrong, Roithmayr claims that policymakers must make intuitive choices between these arguments based on political and moral convictions. ${ }^{66}$ Unfortunately, she never makes clear precisely whose intuitive judgments should govern the policymaking process, nor does she explain whether politics and morality necessarily lead to similar intuitive insights.

\section{A. The Uncertain Identity of Latinos in Civil Rights Policy}

The papers on civil rights in this section present new difficulties in deciphering Latino identity. While Chang and Aoki analogize Latinos to Asian Americans, Roithmayr, to the extent that she addresses the Latino experience at all, treats Latinos as similar to Blacks because both groups have suffered a history of discrimination. To substantiate the analogy to Blacks, she compares both groups' historical exclusion from education

64. See 85 CALIF. L Rev. at 1497, 10 LA RAZA L.J. at 411.

65. See 85 Calif. L Rev. at 1498, 10 LA Raza L.J. at 412.

66. See 85 Calif. L Rev. at 1506, 10 LA Raza L.J. at 420. 
and employment as well as their contemporary failure to meet traditional meritocratic criteria based on GPAs and LSAT scores. Yet, Roithmayr's paper ignores substantial differences between Latinos and Blacks that might matter to policymakers in the affirmative action debate. First and most importantly, Latinos have not been racialized in the same way as Blacks. Because Latinos have not suffered a history of discrimination rooted in slavery, some commentators have argued that Latinos should not be eligible for affirmative action to the same extent as Blacks. ${ }^{67}$ As circumstantial evidence, critics of affirmative action for Latinos point to the very LSAT scores that Roithmayr cites. These critics note that although Latinos' LSAT scores lag belind those of nonHispanic Whites, Latinos are about four times as likely as Blacks to obtain a top score. ${ }^{68}$ Moreover, Latinos have substantially better access than Blacks to integrated housing and have higher rates of intermarriage with non-Hispanic Whites, both traditional measures of assimilation.69 Once Latinos achieve necessary job skills, they are better able than Blacks to obtain appropriate levels of employment and income, even though all but the most elite Latinos clearly continue to pay an ethnicity tax in comparison to non-Hispanic Whites. ${ }^{70}$

Critics of affirmative action programs for Latinos contend that differences in education and employment between Latinos and nonHispanic Whites are an artifact of immigration, rather than invidious discrimination. That is, recent Latino immigrants with low rates of education and training depress overall outcomes for the group. ${ }^{71}$ By contrast,

67. See, e.g., Paul Brest \& Miranda Oshige, Affirmative Action for Whom?, 47 STAN. L. REv. 855, 883-90 (1995); Schuck, supra note 37, at 2001-03.

68. See Roithmayr, 85 CALIF. L. Rev. at 1492, 10 LA RAzA L.J. at 406 (noting that in 1992-93, $25.7 \%$ of White applicants scored 160 or above on the LSAT, while only $11.5 \%$ of Latinos, $12.7 \%$ of Native Americans, and $2.9 \%$ of African Americans did).

69. See Robert M. Jiobu, Ethnicity and Assimilation: Blacks, Chinese, Filipinos, Japanese, KoReans, Mexicans, Vietnamese, and Whites 153-54, 161, 173-74 (1988); Dcnton \& Massey, supra note 26, at 798; Massey \& Denton, supra note 35, at 820; Douglas S. Massey \& Eric Fong, Segregation and Neighborhood Quality: Blacks, Hispanics, and Asians in the San Francisco Metropolitan Area, 69 Soc. FORCES 15, 28 (1990).

70. See Farley, supra note 41 , at $239-40$ (noting that Latino men's earnings are higher than those of Blacks, but lower than those of Whites; a portion of the earnings differential for Latinos appears to reflect an ethnicity tax that prevents them from converting their skills into appropriate occupations and incomes with the same efficacy as Whites); Reimers, supra note 26, at 889 (discussing how Latino family income was higher than that of Blacks as of the 1981 Census); Tienda \& Lii, supra note 37, at 162 (1987) (reporting an earnings differentiation among highly educated Latinos, Asian Americans, and Whites); Wilson, supra note 40, at 258 (noting that Whites hold stereotypes of Blacks that are more negative than those of Latinos).

71. See Brest \& Oshige, supra note 67 , at $886-88,890$ (noting the role of immigration in depressing socioeconomic outcomes for Latinos and analyzing the relevance of this observation to 
the characterization of Black Americans as a racial group subordinated by a history of slavery and inequality has yet to be significantly affected by recent and relatively low levels of immigration. Indeed, when General Colin Powell was touted as a possible Republican candidate for President, he was labeled the first Black with a genuine chance to win this coveted nomination and office. General Powell reminded reporters on several occasions that he thought of himself as a Jamaican immigrant, yet this did little to alter the media's excited headlines about a pathbreaking Black man. ${ }^{72}$

Interestingly, when immigration is noted in conjunction with Black Americans, it plays a role nearly opposite to the one that it occupies in the debate over Latinos and affirmative action. For Latinos, depressed levels of educational and occupational attainment are attributed to immigrant status, not ethnic discrimination. Although there is evidence that the promise of intergenerational mobility is not materializing for all Latinos, the assumption that Latinos will assimilate without special government help remains a powerful force in public policy debates about affirmative action. For Blacks, however, race remains the single most important explanatory variable in evaluating socioeconomic outcomes, regardless of findings about the immigrant experience. For example, when Caribbean immigrants achieve higher rates of education and income than native-born Blacks, the difference is attributed to the devastating consequences of American racism on the latter. ${ }^{73}$ When Caribbean Blacks are found to do no better-or even worse-than

affirmative action policy); see generally Peter Brimelow, Alien Nation: Common Sense ABOut AMERICA's IMmigration DisAster 218, 272 (1995).

72. See Henry Louis Gates, Jr., Powell and the Black Elite, New Yorker, Sept. 25, 1995, at 64-66, 69-70, 76-78 (describing Powell's immigrant origins, which reinforce Whites' perceptions of him as an ideal Black candidate and create doubts among some Blacks that he identifies strongly enough as a Black); Orlando Patterson, The Culture of Caution, New RepuBlic, Nov. 27, 1995, at 22 (noting how Powell's autobiography recounted his roots as a West Indian immigrant and assessing the uneasy relations betwcen West Indians and African Americans).

73. See Roger Waldinger, Still the Promised City?: African-Americans and New IMMigrants IN Postindustrial NEW YoRK 274-76 (1996) (noting the grenter success in the construction industry of immigrant Blacks from the Caribbean when compared to native-born Blacks; in the author's view, "the social and economic structures of the islands expanded the opportunities for relevant skill acquisition"); Kristin F. Butcher, Black Immigrants in the United States: A Comparison With Native Blacks and Other Immigrants, 47 InDus. \& LAB. ReL. Rev. 265, 281-82 (1994) (using 1980 Census data to show that immigrant Blacks have higher rates of employment but earn slightly lower wages than native-boru Black men; the key determinant seems to be migrant behavior because Caribbean Blacks resemble native-born Blacks who move from state to state); Sam Fulwood, U.S. Blacks: A Divided Experience; Animosity Clouds Relations Between Caribbean Immigrants, NativeBorn African Americans, L.A. TIMES, Nov. 25, 1995, at Al (discussing the submerged differences in experience and belief between native-born and immigrant Blacks). 
native-born Blacks, these findings are attributed to the pernicious impact of racism, which saps immigrant initiative. ${ }^{74}$ In either case, researchers conclude that affirmative action remains vital to the successful integration of Black Americans, for whom race is the dispositive factor in shaping access to opportunity regardless of immigrant status.

Because Roithmayr fails to bring Latinos to the center of her analysis, she makes no nuanced contribution to the debate over the distinctions between Latinos and Blacks and how they affect Latinos' entitlements to affirmative action. Elsewhere, I have written about Latinos' ambiguous identity as neither Black nor White, and how this ambiguity influences the perceived legitimacy of Latinos' participation in affirmative action programs. ${ }^{75}$ Without a monolithic racial label, Latinos are presumed to be less disadvantaged than Blacks. This approach at times trivializes the genuine discrimination, both historical and contemporary, that impedes Latinos' educational and economic advancement. The tendency to dismiss depressed levels of income and education among Latinos as a mere artifact of immigration overlooks the ways in which immigration has reinforced and intensified prejudice against Latinos. The ready assumption that Latino immigrants enjoy the privileges of a White ethnic identity ignores the systematic structures of exclusion that block their intergenerational mobility. All of these issues should be central to an examination of affirmative action in which Latino identity really matters.

\section{B. Putting Latinos' Concerns at the Center: The Impact on Civil Rights Policy}

In Cameron's discussion of workplace language rules, Latinos emerge clearly as a distinct group with unique policy needs. Even so, much of the article is devoted to explaining why Latinos are rendered

74. See Philip Kasinitz, Caribbean New York: Black Immigrants and the Politics of RACE 79-85, 93-110 (1992) (noting that Caribbean Blacks have been somewhat successful as entrepreneurs and have made more inroads into the service sector than native-bom Blacks, but that underclass formation is emerging in the form of gangs and crime); Suzanne Model, Caribbean Immigrants: A Black Success Story?, 25 INT'L MIGRATION Rev. 248, 271-73 (1991) (using 1980 Census to question the claim that Caribbean Blacks generally earn more than native-bom Blacks; the convergence in income may result from a growing similarity in family structure between the two groups). But cf. Matthijs Kalmijn, The Socioeconomic Assimilation of Caribbean American Blacks, 74 SOC. FORCES 911, 927-29 (1996) (trying to examine the impact of the immigrant experience itself by demonstrating that British Caribbeans do better while Spanish-speaking and French-speaking Caribbeans do worse than their native-bom counterparts; British Caribbeans seem to be able to preserve their immigrant advantage intergenerationally).

75. See Moran, Unrepresented, supra note 29, at 141-46. 
invisible by a Black/White paradigm of race relations. The piece argues persuasively that Latinos are neither Black nor White, but their alternative identity is not fully elaborated. One might infer that the relevant dimensions of Latino identity for Cameron are national origin, ethnicity, language, and culture, rather than race. Yet, what remains uncertain is how these factors interact in forming an authentic Latino identity. This question is particularly critical for policymakers because of the internal heterogeneity of the Latino population. For example, a third-generation Latino who does not speak Spanish and knows relatively little about his cultural heritage could still be Latino based on ethnicity alone. What sort of protections against ethnic discrimination should this individual enjoy? Do these protections really look all that different from protections agamst racial discrimination afforded to Blacks? Has the Black/White model really hampered the most assimilated Latinos' quest for equal treatment? Perhaps evidence that highly educated Latinos who are fluent in English earn wages comparable to those of Whites suggests that the traditional civil rights model has worked well for them, even if it has failed their less acculturated counterparts.

How has a Black/White paradigm affected opportunities for Latinos who have yet to fully assimilate by learning English and American customs? One of the ironies of the jurisprudence regarding English-only rules is that federal courts have regularly indicated in dictum that monolingual speakers of a language other than English deserve greater protection than bilingual employees. ${ }^{76}$ Because the non-English speaker cannot comply with a directive to use English on the job, judges fear that language can be used as an extremely effective proxy to discriminate on the basis of national origin. Courts therefore appear willing to treat the monolingual non-English speaker as an individual with a trait that can not be readily changed in the short run and that leaves him vulnerable to abuse and discrimination in the meantime. For the fully fluent bilingual employee, however, a workplace language rule is not considered an obstacle to participation because he is readily able to comply by speaking English. Therefore, he can be subjected to intrusive language regulation. In other words, the Black/White paradigm that Cameron describes appears to afford solid protection to the most

76. See, e.g., Garcia v. Spun Steak Co., 998 F.2d 1480, 1488 (9th Cir. 1993); Garcia v. Gloor, 618 F.2d 264, 270 (5th Cir. 1980); see also Long v. First Union Corp. of Virginia, 894 F. Supp. 933, $939-42$ (E.D. Va. 1995), aff d, 86 F.3d 1151 (4th Cir. 1996) (following approach in Spun Steak and Gloor). 
assimilated and the least assimilated Latino, but the partially assimilated Latino is left out.

This apparent anomaly requires a closer examination of the complexity of Latino identity and its impact on public policy. If a Latino is a first-generation immigrant who arrived speaking only Spanish but has struggled to learn English to obtain a job, should this person enjoy the same workplace language protections as a second-generation Latino who grew up speaking only English but subsequently learned Spanish in school to reclaim a sense of limguistic and cultural heritage? Does it make any difference that bilingualism is linked to national origin for the first-generation immigrant and to ethnicity for the secondgeneration Latino? Should it matter that the first-generation immigrant, although bilingual, is more comfortable speaking Spanish than English, while the second-generation Latino is more comfortable speaking English than Spanish but chooses the latter as an expression of ethnic pride? Should these differences bear on a court's assessment of whether a worker's decision to use Spanish on the job is voluntary because compliance is relatively easy?

For many, the instance of the bilingual employee who is more comfortable in Spanish than in English presents a sympathetic case for government protection because the employee seems to be punished for something he cannot change: Spanish is his first language, while English is a laboriously acquired asset. Far from being voluntary, reverting to Spanish seems like an artifact of the employee's status as a newcomer with Spanish-speaking roots. However, courts have examined neither a bilingual person's relative comfort in English and Spanish nor the special burdens of switching back and forth between two languages. In assessing the ability to comply with an English-only rule, the courts have focused exclusively on whether employees are able to speak English. Even if it is burdensome for native-Spanish speakers to use English because it is their second language, judges believe that they must expend the extra effort to do so if the employer wishes it.

Perhaps the courts are reluctant to protect the bilingual employee's right to speak Spanish on the job because it appears to make assimilation optional. In particular, labeling English-only rules for bilingual employees a form of discrimination might empower Latinos to reclaim their linguistic heritage and inject it into the workplace at will, regardless of whether Spanish is their mother tongue. By simply urging the courts to take national origin discrimination against first-generation Latinos seriously, Cameron leaves open the question of how he would deal with the second-generation bilingual employee who chooses to speak 
Spanish as an act of ethnic pride. Should courts treat this as a voluntary act of insubordination, one that puts an employee's personal preferences ahead of an employer's desire for linguistic order and uniformity? Or, is this application of English-only rules also a form of discrimination against Latinos?

These problems lead to the second difficulty with these civil rights analyses. Even if Latinos are depicted in textured and nuanced terms rather than simply analogized to other racial and ethnic groups, the essays leave open a key question: Will a full understanding of Latinos be used simply to extend the traditional civil rights model to them or will it require the creation of new paradigms of inclusion? Predicated on the African-American experience with slavery and the legalized caste system that followed Reconstruction, the traditional civil rights model focuses on correcting past injustices to achieve a colorblind society. Not only do individuals have the right to be free from discrimination, but officials also must eradicate the impact of historical wrongs by using remedies like affirmative action to improve access to education and employment. These remedies are applied without requiring that each beneficiary establish a personal history of discrimination. ${ }^{77}$

This civil rights model is fundamentally assimilationist. It offers the promise that, in the long run, Blacks will compete equally with Whites for desirable jobs and schools in a society finally free of the taint of racial prejudice. Affirmative action is a temporary palliative necessary to counteract past discrimination, but once Blacks are assimilated, the programs will be eliminated. ${ }^{78}$ Roithmayr's paper nestles at the heart of this traditional model. She contends that past discrimination has harmed some groups' access to the traditional indicia of merit. Affirmative action helps these groups to build their portfolios of success. With respect to Latinos, she suggests only that the existing civil rights model be preserved and extended to include a population that, like Blacks, is seriously disadvantaged. Her call for policymakers to rely on their intuitions about social justice does not offer a normative alternative to

77. See Richard Kiuger, Simple Justice: The History of Brown v. BoARd of Education and Black America's Struggle for Equality $32-38$ (1975); J. Harvie Wilkinson III, From Brown to BaKke-The Supreme Court and School Integration: 1954-1978 at 11-23 (1979); Moran, Neither Black Nor White, supra note 29; Moran, Unrepresented, supra note 29, at 142; Moran, supra note 25, at 4-9; see also Deborah Ramirez, Multicultural Empowerment: It's Not Just Black and White Anymore, 47 STAN. L. REv. 957 (1995) (describing expansion of civil rights statutes and affirmative action programs to cover groups other than African Americans and the problems engendered by the growth in protected categories).

78. See Brest \& Oshige, supra note 67 , at $865-67$ (describing compensatory justification for affirmative action). 
the traditional paradigm. Rather, it asks decisionmakers simply to reflect on their sense of unfairness in evaluating civil rights protections. Unfortunately, for a population as little understood as Latinos, such intuitions may not provide a very accurate guide to good policy. Even for Blacks, intuition may seem less appealing than hard evidence of continuing segregation, discrimination, and racial violence.

By simply analogizing Latinos to Blacks, Roithmayr misses the ways in which the ambiguity of Latino identity can alert policymakers to the contradictory impulses behind affirmative action programs. In evaluating the legitimacy of Latino participation in affirmative action in higher education, for example, commentators seldom treat the internal diversity of Latinos as a plus in building a pluralistic academy. Instead, this heterogeneity is viewed only as a daunting complication in determining whether Latinos deserve a compensatory remedy. In particular, analysts worry that some Latinos who have not suffered a history of discrimination will wrongly benefit from affirmative action programs designed primarily to help Blacks. ${ }^{79}$ Ultimately, this critique of Latino participation suggests that the claim that previously excluded groups can enrich and transform institutions has yet to be taken seriously. Rather, affirmative action is still understood mainly as an act of noblesse oblige that permits Blacks and perhaps some disadvantaged Latinos to assimilate to prevailing norms. ${ }^{80}$

While Roithmayr devotes most of her discussion to corrective justice concerns, Cameron more clearly suggests that the traditional civil rights model may be inadequate to address the unique circumstances of Latinos. In particular, by emphasizing the role of language and culture as well as race, ethnicity, and national origin, he appears to be pressing for a pluralistic model of inclusion. Under this approach, Latinos would insist that equality not depend on assimilation to White norms. In Cameron's piece, for example, Latinos could demand that their choice to speak Spanish be respected, even if they speak English as well. Latinos need not "act White" in order to insist on equal treatment in the workplace.

Yet, the pluralist model has implications that potentially go far beyond English-only rules in the workplace. For example, under a pluralist model, the government might have an obligation to assist families to

79. See Moran, Unrepresented, supra note 29 , at 145.

80. See Gabriel J. Chin, Bakke to the Wall: The Crisis of Bakkean Diversity, 4 WM. \& MARY BILL of RIGHTS J. 881, 902-09 (1996) (noting resistance to accepting diversity instead of compensatory rationale for affirmative action in law school admissions). 
preserve their native language and cultural heritage in the public schools. Bilingual schooling and inulticultural curricula would become integral components of achieving a society that respects differences, rather than marginalized and highly controversial areas of the curriculum. ${ }^{81} \mathrm{~A}$ bilingual workplace would affirmatively welcome languages other than English, rather than simply refrain from discrimination against non-English speakers. Signs at the job site might be in multiple languages, unions would have to provide bilingual ballots and translators, and bilingual skills would be affirmatively rewarded through additional compensation. ${ }^{82}$ Cultural expressions-as demonstrated through various styles of dress, religious observance, and dietary restrictions-would have to be accommodated as well.

The debate over assimilation and pluralism is, of course, linked to the one over transnationalism and national identity. Pluralism, like transnationalism, threatens traditional notions of shared community and identity, as distinct linguistic and cultural groups are empowered to preserve their members' ways of life. Many of the same concerns about balkanization and strife arise here, and it would once again be helpful to provide a model of the successful pluralistic workplace. By searching for models of success, policymakers might discover that statutes and regulations are only a small part of the effort necessary to accommodate and respect differences. Top-down measures can dictate a minimum level of tolerance, but workplaces that foster employee participation and

81. For a discussion of different models of the relationship between the State and citizens and its impact on various governmental services, including education, see Rachel F. Moran, Irritation and Intrigue: The Intricacies of Language Rights and Language Policy, 85 Nw. U. L. REv. 790, 814-23 (1991).

82. See David L. Gregory, Union Leadership and Workers' Voices: Meeting the Needs of Linguistically Heterogeneous Union Members, 58 CINN. L. REV. 115, $135-49$ (1989) (describing efforts to ensure that non-English-speaking workers can participate in workplace governance); Pamela G. Rubin, Note, Immigrants as Grievants: Protecting the Rights of Non-English-Speaking Union Members in Labor Arbitration, 8 GEo. 1MMIGR. L.J. 557, 567-71 (1994) (addressing the needs of non-English-speaking workers for language assistance to participate meaningfully in labor arbitration proceedings); see also Perez v. Federal Bureau of Investigation, 707 F. Supp. 891, 911-12 (W.D. Tex. 1988) (finding that bilingual employees should be appropriately rewarded for language skills that their employers treat as an asset, rather than penalized by being relegated to dead-end assignments based on these skills); see generally Barbara J. Flagg, Fashioning a Title VII Remedy for Transparently White Subjective Decisionmaking, 104 YALE L.J. 2009, 2030-51 (1995) (arguing that Title VIl currently requires workers to assimilate to White norms to enjoy legal protection from discrimination and that the statutory framework should be expanded to permit development of pluralistic workplaces in a multicultural society). 
communication may be necessary to convert this abstract norm into the lived, daily experience of employees. ${ }^{83}$

In the employment setting, local participation through inclusive governance processes may be particularly important for those who advocate alternatives to the traditional civil rights model. Once the policy goal is something other than a colorblind society in which previously excluded groups have assimilated to White norms, the specter of government engineering of diverse employment settings looms as a daunting possibility. Few could welcome the prospect of a bureaucracy that declares which linguistic and cultural practices are sufficiently authentic to deserve official protection. Certainly, the specter of government profiles of "real" ethnics is offputting enough to give pause to any who would advocate an officially mandated, pluralistic workplace. For policymakers who advocate pluralism, then, the challenge in the workplace and elsewhere is to protect language and culture without unduly infringing on the autonomy of groups to determine their own ways of life.

\section{CONCLUSION}

At the border, at the workplace, and in higher education, Latinos are forcing America to revisit conventional wisdom about immigration and civil rights by reconsidering popular assumptions about citizenship and identity as well as processes of assimilation and pluralism. In each of these areas, Latinos have sparked identity crises for American institutions. Because of the ambiguities surrounding Latinos, they are at times treated as an opportunity, and at other times as a threat. In immigration debates, Latinos are portrayed alternatively as victims and victimizers. Either the Latino is fleeing economic hardship or political persecution to seek refuge in the United States, or the Latino is an intruder who is stealing work from native-born Americans and jeopardizing American identity. At work, bilingual Latinos are characterized as assets and as liabilities. The Latino can make a unique contribution by translating for customers and monolingual co-workers, but the Latino can disrupt the workplace by using Spanish to exclude monolingual English speakers from the conversation. In higher education, Latino students are finds and frauds. They can bring a unique and previously unrepresented

83. For a fuller discussion of some concerns about top-down and bottom-up pluralism in the school setting, see Rachel F. Moran, Knocking on the Schoolhouse Door and Wondering What's Inside, 4 Berkeley WOMEN's L.J. 259, 276-84 (1989-90); Rachel F. Moran, The Politics of Discretion: Federal Intervention in Bilingual Education, 76 CALF. L. REv. 1249, 1331-51 (1988). 
perspective to the learning process, yet they are unfairly capitalizing on affirmative action without suffering a history of discrimination comparable to that of Blacks.

These articles begin to show that the ambiguities that appear to reside in the category "Latino" in fact reflect longstanding contradictions in institutional philosophies. Because of their complex make-up, Latinos remind us that the normative criteria underlying immigration and civil rights policy are contestable. The uncertainties surrounding Latino identity reside as much in uneasy policy compromises as in the history and circumstances of Latinos themselves. If Latinos successfully emerge from the shadows of the policy process, their participation could help to clarify pressing questions of access and opportunity that the United States faces as a liberal democracy with diverse constituents in a global economy. Then, perhaps, Latinos will really matter in the public policy debate. 
LA RAZA LAW JOURNAL

CALIFORNIA LAW REVIEW 